\title{
Leptin Regulates Dopamine Responses to Sustained Stress in Humans
}

\author{
Paul R. Burghardt, ${ }^{1,2}$ Tiffany M. Love, ${ }^{1}$ Christian S. Stohler, ${ }^{5}$ Colin Hodgkinson, ${ }^{4}$ Pei-Hong Shen, ${ }^{4}$ Mary-Anne Enoch, ${ }^{4}$ \\ David Goldman, ${ }^{4}$ and Jon-Kar Zubieta ${ }^{1,2,3}$ \\ ${ }^{1}$ Molecular and Behavioral Neuroscience Institute, ${ }^{2}$ Department of Psychiatry, and ${ }^{3}$ Department of Radiology, University of Michigan, Ann Arbor, Michigan \\ 48109, ${ }^{4}$ National Institute on Alcohol Abuse and Alcoholism, National Institutes of Health, Bethesda, Maryland 20892, and ${ }^{5}$ University of Maryland School \\ of Dentistry, Baltimore, Maryland 21201
}

Neural systems that identify and respond to salient stimuli are critical for survival in a complex and changing environment. In addition, interindividual differences, including genetic variation and hormonal and metabolic status likely influence the behavioral strategies and neuronal responses to environmental challenges. Here, we examined the relationship between leptin allelic variation and plasma leptin levels with DAD2/3R availability in vivo as measured with $\left[{ }^{11} \mathrm{C}\right]$ raclopride PET at baseline and during a standardized pain stress challenge. Allelic variation in the leptin gene was associated with varying levels of dopamine release in response to the pain stressor, but not with baseline D2/3 receptor availability. Circulating leptin was also positively associated with stress-induced dopamine release. These results show that leptin serves as a regulator of neuronal function in humans and provides an etiological mechanism for differences in dopamine neurotransmission in response to salient stimuli as related to metabolic function. The capacity for leptin to influence stressinduced dopaminergic function is of importance for pathological states where dopamine is thought to play an integral role, such as mood, substance-use disorders, eating disorders, and obesity.

\section{Introduction}

There is substantial evidence implicating dopaminergic neurotransmission in the ventral basal ganglia in appetitive behavior, consistent with its role in reward processing, in addition to its role in responding to salient stressful stimuli (Horvitz, 2000; Tobler et al., 2005). Examination of these processes in states of disease or health is of particular interest given the current obesity epidemic and high recidivism following weight loss. Obese individuals have increased nucleus accumbens/ventral striatum response to highcalorie images as measured with functional magnetic resonance imaging (Rothemund et al., 2007; Stoeckel et al., 2008), but decreased activation of striatal regions to palatable food intake (Stice et al., 2008). Acute states of hunger or satiety influence the activation of the ventral striatum in response to high-calorie food images (Fletcher et al., 2010) and future weight gain has been associated with reduced striatal response to palatable food (Stice et al., 2010). Additionally, the dopamine (DA) system is activated in the response to salient food cues (Roitman et al., 2004) and

Received May 24, 2012; revised Aug. 20, 2012; accepted Sept. 2, 2012.

Author contributions: C.S.S., D.G., and J.-K.Z. designed research;C.S.S. and J.-K.Z. performed research; T.M.L. and C.H. contributed unpublished reagents/analytic tools; P.R.B., T.M.L., C.H., P.-H.S., M.-A.E., and J.-K.Z. analyzed data; P.R.B., D.G., and J.-K.Z. wrote the paper.

This work was supported by NIDA Grants R01 DA 016423, R01 DA 022520, and UL1RR024986 and the NIAAA Intramural Program. We thank the technologists in the PET center in the Department of Nuclear Medicine at the University of Michigan for their contribution to this work.

J.-K.Z. has served as a paid consultant for Eli Lilly and Co., Johnson \& Johnson, Merck, and Abbott in the 3 year period before submission of this article. All other authors report no financial conflicts of interest.

Correspondence should be addressed to Paul R. Burghardt, Molecular and Behavioral Neuroscience Institute, The University of Michigan, 209 Zina Pitcher Place, Ann Arbor, MI 48109. E-mail: pburghar@umich.edu.

DOI:10.1523/JNEUROSCI.2521-12.2012

Copyright $\odot 2012$ the authors $\quad 0270-6474 / 12 / 3215369-08 \$ 15.00 / 0$ baseline function is altered in obese humans (Volkow et al., 2008).

A number of biological systems are involved in energy balance, with the leptin system being one of the most studied. Leptin is a hormone secreted from adipose tissue that signals satiety and promotes decreased food intake and increased energy expenditure (Halaas et al., 1995), with circulating levels proportional to fat mass (Ostlund et al., 1996). Dopaminergic neurotransmission in the ventral basal ganglia plays an integral role in the response to salient rewarding stimuli, including drugs of abuse, sex, social bonding, and food (Berridge and Robinson, 1998), and work in animal models suggests leptin modulates central DA function (Fulton et al., 2006; Roseberry et al., 2007; Leinninger et al., 2009). Treatment with exogenous leptin reduces activation of the nucleus accumbens/ventral striatum in leptin-deficient individuals in response to pictures of food and activation correlated with liking the pictures (Farooqi et al., 2007). Leptin is known to influence endocrine response to stress (Wilson et al., 2005) and alter stress-induced food consumption (Appelhans, 2010). This suggests that leptin regulates nucleus accumbens responsivity to salient stimuli in humans and that this hormone is important for motivational drives related to hunger that may be additionally influenced by stress.

Given the role for DA neurotransmission in responding to salient stimuli and the literature implicating leptin as a mediator of central monoamine function, we sought to determine the relationship between the leptin and central dopaminergic systems using $\left[{ }^{11} \mathrm{C}\right]$-raclopride PET in response to a standardized stress challenge that robustly activates DA release (Scott et al., 2006; Wood et al., 2007) and does not rely on food or pharmacologic 
compounds. Common polymorphisms of $L E P$ were captured in a custom-made array (Hodgkinson et al., 2008) and used to assess interindividual variation in dopaminergic system function in humans using a direct measure of DA activity. Under those conditions, endogenous DA release during the challenge is reflected by reductions in the in vivo availability of DA-D2/D3 receptors from baseline to challenge conditions, which were then related to LEP polymorphisms and circulating leptin levels.

\section{Materials and Methods}

\section{Subjects}

Volunteers were 50 healthy, medication-free, right-handed men $(n=22)$ and women $(n=28) 26 \pm 5$ years of age, with an educational level of $17 \pm 2$ years. Subjects had no personal history of physical or psychiatric illness, or substance abuse or dependence, and no family history of inheritable illnesses, ascertained by physical examination, personal and family history, and review of symptoms. The Structured Clinical Interview for Diagnostic and Statistical Manual of Mental Disorders (DSM-IV nonpatient version) (First et al., 1995) was used to rule out undiagnosed psychiatric illness and substance abuse. Volunteers did not take psychotropic medications or hormone treatments, including birth control in women, for at least 6 months, were nonsmokers, and did not exercise in excess of $1 \mathrm{~h}$ three times a week and were not involved in competitive exercise. All volunteers were instructed not to eat $3 \mathrm{~h}$ before the neuroimaging session. Half the subjects were scanned in the morning and the other half were scanned in early afternoon. Women were studied in the follicular phase of the menstrual cycle (days 4-12 after initiation of menses). Written informed consent was obtained in all cases. All of the procedures used were approved by the institutional Investigational Review Board and the Radioactive Drug Research Committee.

\section{Pain stress challenge}

Pain was maintained for 45-65 min after the administration of radiotracer by the infusion of medication-grade $5 \%$ hypertonic saline into the relaxed masseter (jaw) muscle via a computer-controlled closed-loop system, as described previously (Zhang et al., 1993; Stohler and Kowalski, 1999). First, the subject-specific parameters of the system for maintaining muscle pain are established. This consists of measuring each subject response to a standard bolus injection of $0.15 \mathrm{ml}$ of hypertonic saline, infused over $15 \mathrm{~s}$. A suitable infusion rate is then estimated by comparing the individual response with the mean response of 65 individuals exposed to the same bolus. Subsequently, the adaptive controller depends on feedback from the subjects. Subjects were required to report the present pain intensity every $15 \mathrm{~s}$ on an electronic version of $100 \mathrm{~mm}$ visual analog scale (VAS), with the lower and upper bound of the scale marked with numbers 0 and 100, respectively, representing the range from "no pain" to "the most pain intensity imaginable." Based on the VAS pain intensity scores provided by the subject every $15 \mathrm{~s}$ for the reminder of the experiment, individual infusion requirements were continuously modeled and updated to keep the present pain intensity scores in the target range (40 VAS intensity units; range, 30-50) for the full duration of the experiment (Stohler and Lund, 1995; Zubieta et al., 2001). Infusion volumes, required to maintain the preset pain intensity, were recorded every $15 \mathrm{~s}$, and the cumulative infusion volume required over time was used as an indicator of subjects' sustained pain sensitivity. Using this model, pain disappears 5-10 min after completion of the algesic infusion. To avoid swelling and potential tissue damage, the maximum infusion rate was limited to $250 \mu \mathrm{l} / \mathrm{min}$.

\section{Determination of single nucleotide polymorphism in the leptin} gene and circulating leptin levels

Before the PET scan, blood samples were collected into EDTA-treated tubes. Whole blood was stored at $-80^{\circ} \mathrm{C}$ until DNA extraction and analysis. Samples processed for hormonal analysis were placed on ice until they were centrifuged for $10 \mathrm{~min}$ at $3000 \mathrm{rpm}$ and $4^{\circ} \mathrm{C}$. Following centrifugation, plasma was aliquotted and stored at $-80^{\circ} \mathrm{C}$ until assay. Circulating leptin levels were determined using a commercially available ELISA kit (Assay Designs) per the manufacturer's instructions. Samples
Table 1. Genotype frequencies for alleles in the LEP gene

\begin{tabular}{|c|c|c|c|c|}
\hline LEPSNPS & \multicolumn{3}{|c|}{$n$, Genotype frequencies } & MAF \\
\hline rs 12706832 & $15, \mathrm{AA}(0.30)$ & 21, AG (0.42) & $14, \mathrm{GG}(0.28)$ & 0.50 \\
\hline rs3828942 & $12, \mathrm{AA}(0.24)$ & 20, AG $(0.40)$ & $18, \mathrm{GG}(0.36)$ & 0.44 \\
\hline rs7791621 & $48, \mathrm{AA}(0.96)$ & $2, \mathrm{AC}(0.04)$ & $0, C C(0)$ & 0.02 \\
\hline rs7795794 & $0, A A(0)$ & $3, \mathrm{AG}(0.06)$ & $47, \mathrm{GG}(0.94)$ & 0.06 \\
\hline
\end{tabular}

MAF, Minor allele frequency.

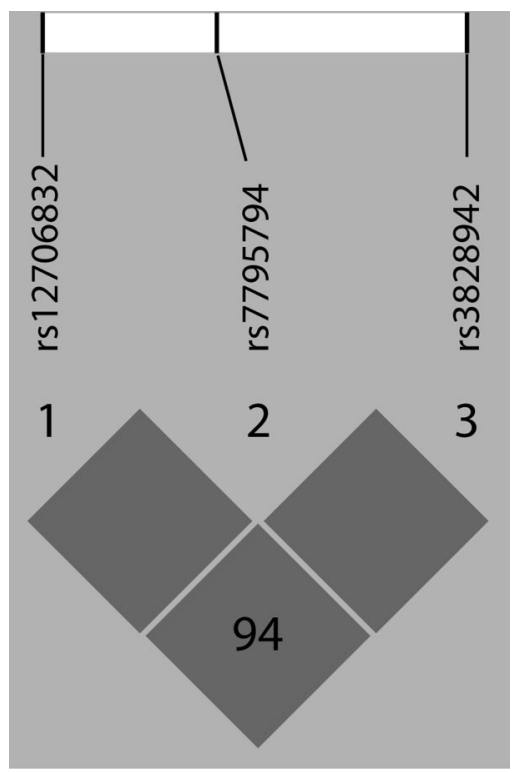

Figure 1. Linkage disequilibrium expressed as $D^{\prime}$ in the study population.

from all subjects were run in the same batch, and the average coefficient of variation for within-subject replicates was $3.2 \%$.

\section{Genotyping}

Tagging single-nucleotide polymorphisms. A genomic region containing sequences $5 \mathrm{~kb}$ upstream and $1 \mathrm{~kb}$ downstream of $L E P$, mapped to chromosome 7q31.1, was retrieved from NCBI Human Build 35.1. Haplotype-tagging single-nucleotide polymorphisms (SNPs) were identified using a previously described design pipeline (Hodgkinson et al., 2008). Four haplotype-tagging SNPs (rs12706832, rs3828942, rs7791621, and rs7795794), located in intronic noncoding regions just upstream/ downstream to $L E P$, were genotyped using the Illumina GoldenGate platform. Genotype and allele frequencies are shown in Table 1. The genotype frequencies for all four SNPs were in Hardy-Weinberg Equilibrium. The $L E P$ haplotype block structure for these SNPs (Fig. 1) shows high linkage disequilibrium among the SNPs. Due to the lack of allelic variation in the rs7791621 and rs7795794 SNPs, we only included rs12706832 and rs3828942 in our analysis and significance was set at $\alpha=$ 0.025 to correct for multiple comparisons.

Assessment of population stratification using ancestry informative markers. The samples were genotyped for 186 ancestry markers (AIMs) (Hodgkinson et al., 2008). The same AIMs were genotyped in 1051 individuals from the 51 worldwide populations represented in the HGDPCEPH Human Genome Diversity Cell Line Panel (http://www.cephb.fr/ HGDP-CEPH-Panel). Structure 2.2 (http://pritch.bsd.uchicago.edu/ software.html) was run simultaneously using the AIMs genotypes from our sample and the $51 \mathrm{CEPH}$ populations to identify population substructure and compute individual ethnic factor scores. This ancestry assessment identifies seven ethnic factors (Hodgkinson et al., 2008). In our study sample, the predominant mean (SD) [median] ethnic factor scores were as follows: European: 0.65 (0.39) [0.89]; African: 0.12 (0.29) [0.00]; Asian: 0.11 (0.25) [0.02]; Mid-Eastern: 0.07 (0.17) [0.02]; and Far Eastern: $0.02(0.09)[0.00]$. Since the sample was predominantly Caucasian, the European ethnic factor score was included as a covariate in all analyses to account for the variability in allele frequencies across ethnicities. 
Neuroimaging. Anatomical MRI scans were acquired on a 3 Tesla scanner (General Electric). Acquisition sequences were axial SPGR inverse recovery-prepared $\mathrm{MR}$ (echo time $=3.4 \mathrm{~ms}$, repetition time $=10.5 \mathrm{~ms}$, inversion time $=200 \mathrm{~ms}$, flip angle $=25^{\circ}$, number of excitations $=1,124$ contiguous images, $1.5 \mathrm{~mm}$ thickness).

PET scans were acquired with a Siemens $\mathrm{HR}^{+}$scanner in threedimensional mode [reconstructed full-width at half-maximum (FWHM) resolution, $\sim 5.5 \mathrm{~mm}$ in-plane and $5.0 \mathrm{~mm}$ axially], with septa retracted and scatter correction. Participants were positioned in the PET scanner gantry using the orbitomeatal line aided by the scanner gantry laser lights, and two intravenous (antecubital) lines were placed. A light forehead restraint was used to eliminate intrascan head movement. $\left[{ }^{11} \mathrm{C}\right]$ raclopride was synthesized at high specific activity $(>2000 \mathrm{Ci} / \mathrm{mmol})$ by the reaction of $O$-desmethyl raclopride with $\left[{ }^{11} \mathrm{C}\right]$ methyl triflate; $15 \pm 1$ $\mathrm{mCi}$ were administered in each of the two scans. Fifty percent of the $\left[{ }^{11} \mathrm{C}\right]$ raclopride dose was administered as a bolus, and the remaining $50 \%$ was administered by continuous infusion for the remainder of the study. Under these conditions, equilibrium conditions are achieved after 35 min after tracer administration (Carson et al., 1997). Twenty-eight frames of images were acquired over $90 \mathrm{~min}$ with an increasing duration (30 s-10 min). The total mass of raclopride injected was $0.09 \pm 0.05$ $\mu \mathrm{g} / \mathrm{kg}$ per scan, ensuring that the compound was administered in tracer quantities, i.e., subpharmacological doses. Images were reconstructed using iterative algorithms (brain mode; Fourier rebinning with ordered subsets-expectation maximization, 4 iterations, 16 subsets; no smoothing) into a $128 \times 128$ pixel matrix in a $28.8 \mathrm{~cm}$ diameter field of view. Attenuation correction was performed through a 6 min transmission scan $\left({ }^{68} \mathrm{Ge}\right.$ source) obtained before the PET study, also with iterative reconstruction of the blank/transmission data, followed by segmentation of the attenuation image. Small head motions between emission scan frames were corrected by an automated computer algorithm for each subject before analysis, and the images were coregistered to each other with the same software (Minoshima et al., 1993). Time points were then decay-corrected during reconstruction of the PET data. Image data were then transformed on a voxel-by-voxel basis into two separate sets of parametric maps. In all cases, these included a tracer transport measure $\left(\mathrm{K}_{1}\right.$ ratio $)$ and receptor-related measures at equilibrium (DVeq). The DVeq measure was obtained using the ratio of brain activity to activity in the cerebellum (Carson et al., 1997; Watabe et al., 2000); $f_{2} B \max / K d$ (or DVeq - 1) was the receptor-related measure [DA D2/3 receptor availability, binding potential-equilibrium (BPeq); the term $f_{2}$ refers to the concentration of free radiotracer in the extracellular fluid and is considered to represent a constant and very small value]. Baseline BPeq values were obtained from 35 to $45 \mathrm{~min}$ after tracer administration using identical methods. BPeq values after the pain stress challenge were calculated using data obtained 45-90 min after tracer administration. The reduction in BPeq from baseline to challenge periods is used as a measure of neurotransmitter release and activation of DA neurotransmission (Carson et al., 1997).

Raclopride is an antagonist at the level of both D2 and D3 receptors. In the dorsal basal ganglia, this radiotracer only binds to D2 receptors, whereas in the ventral basal ganglia, one-third of the signal may be contributed by D3 receptors (Seeman et al., 2006). Findings in dorsal regions will then be referred to as reflecting DA D2 neurotransmission, and DA D2/D3 in ventral areas. $K_{1}$ and BPeq images for each experimental period and magnetic resonance images were coregistered to each other and to the International Consortium for Brain Mapping (ICBM) stereotactic atlas orientation (Meyer et al., 1997). The accuracy of coregistration and nonlinear warping algorithms was confirmed for each subject individually by comparing the transformed MRI and PET images with each other and the ICBM atlas template.

Image data analysis. Differences between conditions were mapped into stereotactic space using $t$ maps of statistical significance and random effects with SPM5 and Matlab software (MathWorks), with a general linear model and correction for multiple comparisons (Friston et al., 1995). No global normalization was applied to the data, and therefore the calculations presented are based on absolute BPeq estimates. Only regions with specific $\mathrm{DAD} 2 / \mathrm{D} 3$ receptor $\mathrm{BP}$ were included in the analyses (voxels with BPeq $>$ 0.2 ). To compensate for small residual anatomic variations across subjects and to improve signal-to-noise ratios, a three-dimensional Gaussian filter
(FWHM of $6 \mathrm{~mm}$ ) was applied to each scan. Significant effects were detected using a statistical threshold that controls a type I error rate at $p=0.025$ after correction for multiple comparisons [false discovery rate (FDR)]. These were estimated using the Euler characteristic (Worsley et al., 1992) based on the number of voxels in the gray matter and image smoothness and the extent of local changes (correction for cluster volume; FDR correction at $p<$ 0.05) (Friston et al., 1991). Numerical values for the changes in DA D2/D3 $\mathrm{BPeq}$, as well as for the calculation of correlations and $r$ values, were extracted from the image data by averaging the values of voxels contained in an area in which significant effects were obtained in the voxel-by-voxel analyses, down to a threshold of $p=0.01$.

Extracted PET data were used for ANOVA analyses of effects of SNP genotype. The relationship between SNP genotype and circulating leptin levels were investigated by multiple linear regression. Correlations between variables were tested with Pearson correlations at $p<0.05$. Other comparisons are described in the text. Data in the text is expressed as the mean $\pm \mathrm{SD}$, graphs represent mean \pm SEM.

\section{Results}

\section{Influence of allelic variation in the leptin gene on stress- induced dopamine release}

We identified significant effects of LEP SNP (rs12706832) genotype on stress-induced DA release in three significant peaks (Fig. 2), controlling for body mass index (BMI), sex, and AIMs score. A large cluster was found in the right ventral striatum that encompassed the nucleus accumbens, caudate head, and putamen $(x=$ $20, y=18, z=-5 ; k=1595 ; z=13.33, p=0.005$, FDR corrected). Additionally, two smaller peaks were found in the left ventral striatum in a cluster that included the nucleus accumbens $(x=-11, y=9, z=-4 ; k=279 ; z=3.82, p=0.009$, FDR corrected), and the left putamen $(x=-31, y=4, z=0 ; k=635$; $z=3.74, p=0.01$, FDR corrected). No association among allelic variants was found for SNP rs3828942, and the discussion of allelic variation in LEP refers to the SNP rs12706832 genotypes from here on out.

Data were extracted from the regions identified above for secondary analysis, which revealed that the GG genotype showed greater stress-induced DA release in response to stress in the left nucleus accumbens $\left(F_{(2,47)}=4.11, p=0.02\right)$, left putamen $\left(F_{(2,47)}=5.05, p=0.01\right)$, and right ventral striatum $\left(F_{(2,47)}=\right.$ $5.59, p=0.006)$ in a right ventral striatum cluster that extended from the nucleus accumbens to the caudate head and the ventral putamen (Fig. 2). Baseline BPeq or circulating levels of leptin were not significantly associated with genotype $\left(F_{(2,47)}=0.37\right.$, $p=0.7$; Table 2). Although we did not find a relationship between SNP genotype and circulating leptin levels, the lack of association may be due to interindividual variation in leptin levels described previously (Licinio et al., 1997).

Plasma levels of leptin (ng/ml; range, 1.7-90.7; mean $\pm \mathrm{SD}$, $18.1 \pm 19.6)$ were positively correlated with BMI $\left(\mathrm{kg} / \mathrm{m}^{2}\right.$; range, $16.9-37.4 ; 25.5 \pm 4.3)(r=0.49, p=0.0002)$. The above extracted data on allelic effects on regional stress-induced DA release were positively correlated with circulating levels of leptin in both left and right peaks. As a group, women had higher circulating leptin then men; however, a great deal variability was evident in both men and women. To determine the overall relationship between leptin and dopamine, our analyses included sex as a covariate. No significant correlations between stressinduced DA release and BMI were obtained (Table 3).

\section{Relationship between circulating leptin and stress-induced dopamine release}

An additional analysis was performed using a regression model on a voxel-by-voxel basis, with circulating leptin levels as a re- 

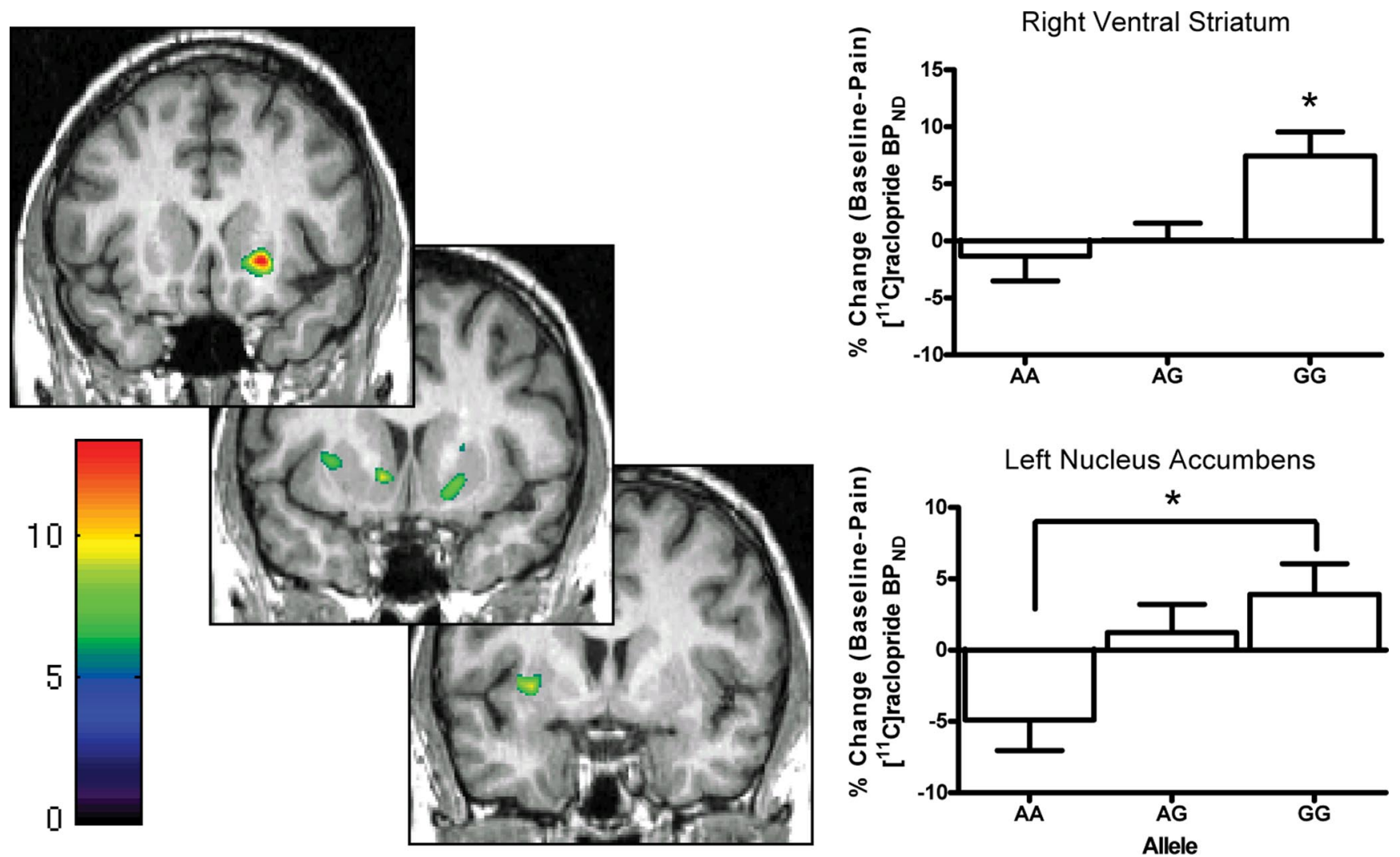

Figure 2. Dopamine release in response to pain-stress is differentially modulated by allelic variation of the rs 12706832 SNP in the Leptin gene. The localization of changes in [ $\left.{ }^{11} \mathrm{C}\right] \mathrm{raclopride}$ binding potential-nondisplaceable $\left(\mathrm{BP}_{\mathrm{ND}}\right)$ in the ventral striatum following pain-stress as they relate to individual allelic variation in rs12706832 SNP are shown on the left. The left side of the image corresponds to the left side of the body (neurological convention), which is ipsilateral to the pain stimulus. Color scale relates to $z$-scores. The bar graphs illustrate the change in $\left[{ }^{11} \mathrm{C}\right]$ raclopride binding potential-nondisplaceable extracted from the right ventral striatum and left nucleus accumbens. Data are represented as mean $\pm \mathrm{SEM}$. ${ }^{*}, \mathrm{GG}>\mathrm{AG}$ and $\mathrm{AA}$ (top right); *, $\mathrm{GG}>\mathrm{AA}$ (bottom right).

Table 2. Circulating leptin levels by genotype

\begin{tabular}{lllll}
\hline LEPSNPs & Genotype & Circulating leptin $(\mathrm{pg} / \mathrm{ml})$ & $F_{(2,42)}$ & $p$ \\
\hline rs12706832 & AA & $13.9 \pm 11.1$ & 0.37 & 0.69 \\
& AG & $22.4 \pm 24.6$ & & \\
& GG & $12.6 \pm 16.4$ & & \\
rs3828942 & AA & $19.8 \pm 23.6$ & 0.58 & 0.63 \\
& AG & $20.6 \pm 23.2$ & & \\
& GG & $14.5 \pm 12.6$ & & \\
\hline
\end{tabular}

Circulating leptin is mean $\pm S D$.

gressor, including BMI, sex, and AIMs as nuisance variables. Circulating leptin was associated with greater stress-induced DA release in two distinct peaks (Fig. 3; Table 2). Significant peaks were identified in the left anterior head of the caudate nucleus $(x=19, y=22, z=-10 ; k=278 ; t=4.74, p=0.01$, FDR corrected) and a cluster in the left ventral striatum that encompassed the nucleus accumbens and caudate $(x=-14, y=4, z=$ $-9 ; k=432 ; t=4.97, p=0.01$, FDR corrected). The second cluster was identified in the same anatomical region as the peak identified from the analysis of rs12706832. No effects of BMI or AIMs scores were observed, with no suprathreshold voxels even when using a very liberal exploratory threshold of $p=0.05$ uncorrected.

Contrary to the relationships with stress-induced DA release, baseline DA D2/3 BPeq was not significantly associated with circulating leptin, nor with BMI or AIMs scores.

\section{Discussion}

This study directly links the leptin system with central dopaminergic function in the context of a universal stressor, moderate levels of sustained pain, in humans. Our results show that genetic variation in the LEP gene is related to divergent DA release in response to a salient stressor. Furthermore, we found a positive a relationship between circulating leptin levels and DA release in response to this salient stress stimulus. No significant effects of LEP genotype or circulating levels of leptin on baseline DA D2/3 receptor availability were observed, suggesting that this effect is selectively related to DA presynaptic function. Together, these results suggest that leptin serves as a regulator of mesolimbic dopamine system during stressful, salient aversive states.

\section{Leptin regulates dopaminergic response to salient stimuli}

An initial analysis focused on allelic variations in rs12706832, a SNP in the LEP gene, reveals that GG homozygous individuals exhibit greater DA release bilaterally in the ventral striatum in response to the experimental stressor. However, to date no function has been linked with allelic variations in the intronic SNP rs12706832. To further determine leptin-DA relationships, we examined the potential relationships between circulating levels of leptin and stress-induced DA release in data extracted from the above analyses, as well as on a voxel-by-voxel basis. Extracted regional data showed significant relationships between circulating leptin and stress-induced DA release in the regions where genotype effects were observed. Circulating leptin levels were not related to LEP genotype; however, this may be due to individual variability of circulating leptin over time (Licinio et al., 1997).

Voxel-by-voxel analyses using circulating leptin as a regressor and controlling for sex, BMI, and AIMs scores revealed significant clusters in the left nucleus accumbens and left caudate head. 
Table 3. Stress-induced dopamine release correlates with leptin, but not BMI

\begin{tabular}{|c|c|c|c|c|c|}
\hline & rs12706832 & & & Circulating lept & \\
\hline & Left NAC & Left putamen & Right ventral striatum & Left NAC & Left caudate \\
\hline Leptin & $r=\mathbf{0 . 4 0 1 1 6}$ & $r=0.35568$ & $r=0.44863$ & $r=\mathbf{0 . 6 3 5 7 8}$ & $r=0.48139$ \\
\hline & $p=\mathbf{0 . 0 0 3 9}$ & $p=0.0112$ & $p=0.0011$ & $p<0.0001$ & $p=0.0005$ \\
\hline BMI & $r=0.06688$ & $r=0.00087$ & $r=-0.02378$ & $r=0.1745$ & $r=0.11603$ \\
\hline & $p=0.6445$ & $p=0.9952$ & $p=0.8698$ & $p=0.2355$ & $p=0.4323$ \\
\hline
\end{tabular}

Correlations between circulating leptin and BMI with dopamine release in peaks identified during the analysis of the leptin SNP rs 12706832 and circulating leptin levels. Significant correlations are highlighted in bold text. NAC, Nucleus accumbens.
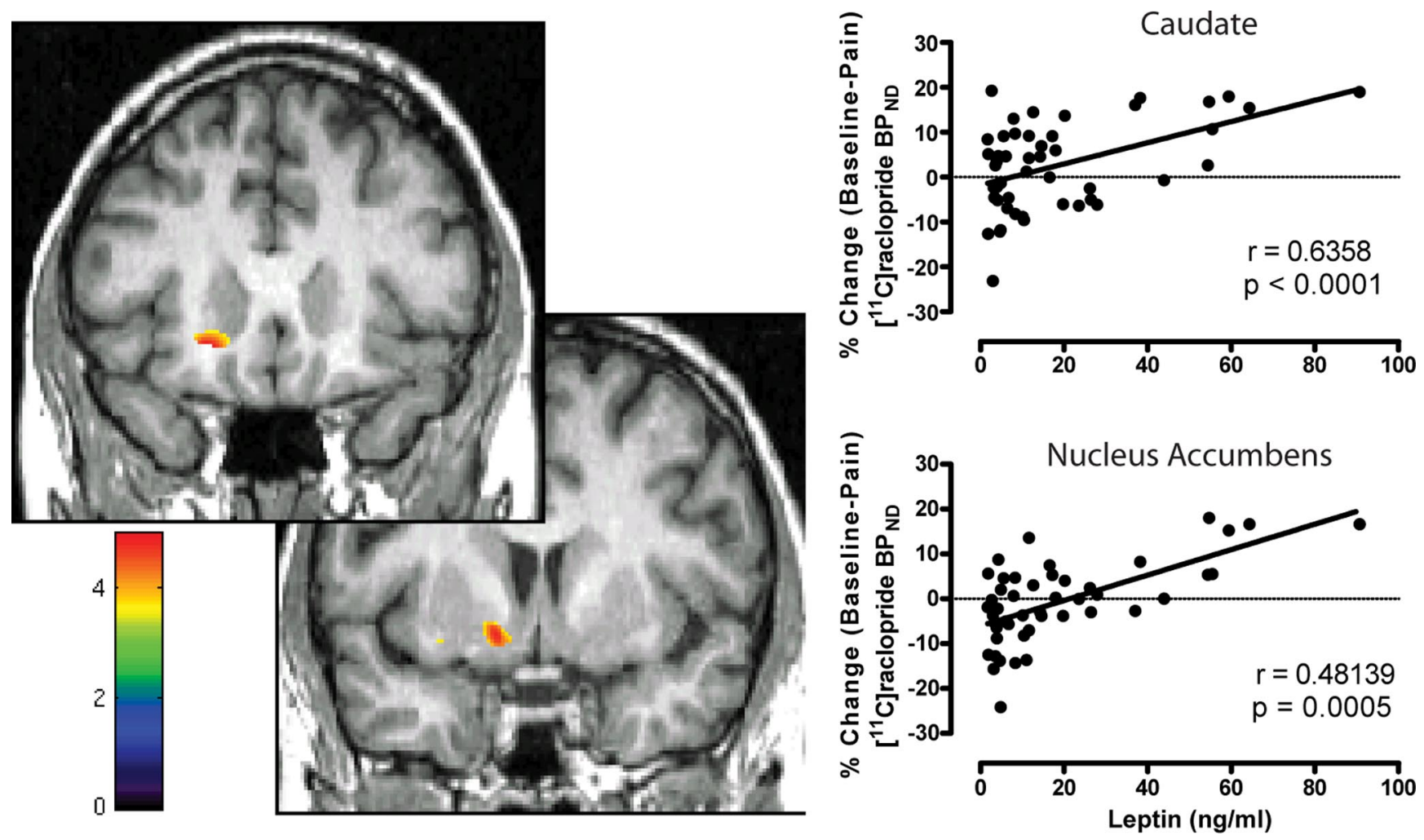

Figure 3. Dopamine release in response to pain-stress is positively related to circulating leptin levels. Left, Localization of changes in $\left[{ }^{11} \mathrm{C}\right]$ raclopride $\mathrm{BP}$ in the ventral striatum following pain stress as they relate to circulating leptin levels. Right, Scatter plots show the relationship between percentage change $\left[{ }^{11} \mathrm{C}\right]$ raclopride binding potential-nondisplaceable $\left(\mathrm{BP}_{\mathrm{ND}}\right)$ in the cluster encompassing the ventral striatum and nucleus accumbens and Caudate with circulating leptin. Color scale relates to $t$-scores.

The cluster identified in the nucleus accumbens with circulating leptin was localized to the same anatomical region as the cluster that included the left nucleus accumbens identified in the SNP analysis. Baseline DA D2/3 BPeq was not related to circulating leptin levels after full correction for multiple comparisons. These data are in line with a recent report using $\left[{ }^{18} \mathrm{~F}\right]$ fallypride PET in a small sample of patients diagnosed with hereditary lipodystrophy where replacement with leptin failed to alter DA D2/3 availability (Ishibashi et al., 2012). However, the use of more liberal thresholds of significance ( $p=0.01$, uncorrected for multiple comparisons) revealed positive correlations with leptin (controlling for sex, BMI, and AIMs) and DA D2/3 BPeq observed in the ventral basal ganglia bilaterally (data not shown).

Somewhat unexpectedly, we did not find an association between BMI and dopaminergic function. It is known that circulating leptin levels are positively correlated with BMI (as they were for subjects in this study) and are proportional to fat mass (Ostlund et al., 1996). Given previous reports of the negative association between BMI and dopaminergic function (Haltia et al., 2007; Volkow et al., 2008) along with the linkage between fat mass and leptin, we examined this potential association in our subjects.
Neither baseline DA D2/3 BPeq nor stress-induced dopamine release was related to $\mathrm{BMI}$ in our data. Previous work finding negative associations between BMI and DA receptor availability has compared individuals with high BMI scores to those with low scores (Wang et al., 2001; Volkow et al., 2008; de Weijer et al., 2011), although there are inconsistent reports on the relationship between dopamine function and BMI in humans, which may be due to methodological differences across studies (Ziauddeen et al., 2012). The work presented here suggests that neurohormonal systems such as leptin may be more robust modulators of dopamine response, and BMI may be a corollary of the physiological changes associated with chronic disease. The subjects in this study were healthy and had a relatively restricted range for BMI. The discrepancy between our findings and previous work may also be related to the type of food consumed or the pattern of consumption exhibited by the individual (Wang et al., 2001; Volkow et al., 2008), where highly palatable food choices that stimulate the DA system would result in downregulation of DA receptors in the basal forebrain and negative correlations between DA receptor availability in vivo and BMI. However, plasma levels of leptin have been found positively correlated with CSF 
levels of DA in healthy individuals, independent of BMI (Hagan et al., 1999), consistent with the results presented here. Collectively, this body of research suggests that the relationship between central DA system function and leptin may be additionally influenced by chronic pathological states like obesity, where central leptin insensitivity may inhibit dopaminergic response to salient stimuli.

\section{Leptin as a regulator of saliency}

Multiple brain regions are involved in assessing saliency and the emotional value of environmental stimuli that predict reward or threat, including the nucleus accumbens, caudate, putamen, amygdala, insular cortex, hippocampus, hypothalamus, and several cortical regions (Breiter and Rosen, 1999). These systems create a network that responds to stimuli of various types including cued eating (Petrovich et al., 2005), pain (Scott et al., 2006; Baliki et al., 2010), and other salient stimuli (Zink et al., 2003, 2004, 2006). Within these regions, several neurotransmitter systems are involved in the response to salient stimuli, including the endogenous opioid and DA systems (Scott et al., 2006, 2007; Amato et al., 2011). Dopaminergic neurotransmission in the ventral basal ganglia plays an integral role in the response to salient rewarding stimuli including drugs of abuse, sex, social bonding, and food (Berridge and Robinson, 1998). Further, the dopaminergic system appears to be influenced by an individual's metabolic phenotype, as obese individuals show lower levels of DA D2 receptor binding compared with lean individuals (Volkow et al., 2008), and leptin influences the neuronal response to salient stimuli related to food in the diseased state (Farooqi et al., 2007; Rosenbaum et al., 2008; Stice et al., 2008, 2011; Ishibashi et al., 2012).

It has long been known that stress has the capacity to influence the response to positive and negative salient stimuli. Pain (Gear et al., 1999; Schmidt et al., 2002), acute stress (Abercrombie et al., 1989; Cenci et al., 1992), and salient cues previously paired with stressors (Pezze et al., 2001) increase extracellular DA in the nucleus accumbens. Recent work highlights leptin's ability to modulate the limbic-hypothalamic-pituitary-adrenal (LHPA) axis at central corticotrophin-releasing hormone systems (Schwartz et al., 1996), as well as the pituitary and adrenals (Walker, 2005; Malendowicz et al., 2007). Leptin reduces basal ACTH and corticosterone (Nowak et al., 2002) and enhances glucocorticoid negative feedback in response to novelty in nonhuman primates (Wilson et al., 2005). Leptin-deficient ob/ob mice have elevated corticosterone (Garthwaite et al., 1980), which is reduced by leptin replacement (Arvaniti et al., 2001). Interestingly, leptin insensitivity may exacerbate LHPA dysregulation (Collura et al., 2009).

Rodent models have begun to illuminate the detailed underpinnings of leptin's ability to modulate responses to salient stimuli through the modulation of dopamine by leptin receptors. Anatomically, leptin receptors are located in brain regions that influence dopaminergic neurotransmission, including areas of DA synthesis (Figlewicz et al., 2003), projection sites (Corp et al., 1998), and via leptin receptor-expressing neurons of the lateral hypothalamus that modulate dopaminergic neurons in the ventral tegmental area (Leinninger et al., 2009). Depending on the anatomical target, the role of centrally administered leptin in regulating dopamine-dependent behaviors (Figlewicz et al., 2004, 2006) and dopaminergic neuronal firing (Liu et al., 2011) can be fairly nuanced. The positive association we report between circulating leptin and dopamine release in humans parallels reports of systemically administered leptin enhancing neurobehavioral responses to dopamine-activating compounds (Fulton et al., 2006) and dopaminergic neuronal activity (Roseberry et al., 2007), which is most evident during activation of the system as opposed to basal conditions.

The relationship among leptin, dopamine, and stress is intriguing from a functional standpoint, as hunger interacts with the energy content of food and modulates activation of several limbic regions, including the caudate and putamen in humans (Siep et al., 2009). In addition, higher circulating leptin was associated with lower snack consumption following stress, and was not a significant predictor of overall or stress-induced changes in hunger (Appelhans, 2010). Reward signaling and sensitivity were lower following stress, which coincided with increased energy intake from foodstuffs that had a higher subjective crispness and fullness of taste (Born et al., 2010). Together, these results suggest that stress interacts with the leptin system's ability to modulate the dopaminergic response to salient cues and may have implications for stress-induced eating. Further, effective leptin signaling to central dopaminergic systems may facilitate an individual's ability to attend to other salient cues (e.g., threat, stress, mating opportunities) en lieu of salient food-related cues.

The studies presented here implicate leptin in the regulation of the dopaminergic system in response to salient stress stimuli not directly linked to food. Effective leptin signaling to the central dopaminergic systems may influence an individual's ability to attend to other salient cues, which appears to be influenced by biological changes secondary to disease and stress. Given the current rates of obesity, modulation of dopaminergic response to salient stimuli by hormones that regulate energy balance will have implications for the treatment of obesity and related diseases. Future examination of these processes, including a more detailed mapping of $L E P$ polymorphisms to DA function, appears warranted, given the role of the dopaminergic system in a number of pathological states that involve a dysregulation of motivated behavior, such as substance use, eating, and mood disorders.

\section{References}

Abercrombie ED, Keefe KA, DiFrischia DS, Zigmond MJ (1989) Differential effect of stress on in vivo dopamine release in striatum, nucleus accumbens, and medial frontal cortex. J Neurochem 52:1655-1658. CrossRef Medline

Amato D, Natesan S, Yavich L, Kapur S, Müller CP (2011) Dynamic regulation of dopamine and serotonin responses to salient stimuli during chronic haloperidol treatment. Int J Neuropsychopharmacol 14:13271339. CrossRef Medline

Appelhans BM (2010) Circulating leptin moderates the effect of stress on snack intake independent of body mass. Eat Behav 11:152-155. CrossRef Medline

Arvaniti K, Huang Q, Richard D (2001) Effects of leptin and corticosterone on the expression of corticotropin-releasing hormone, agouti-related protein, and proopiomelanocortin in the brain of ob/ob mouse. Neuroendocrinology 73:227-236. CrossRef Medline

Baliki MN, Geha PY, Fields HL, Apkarian AV (2010) Predicting value of pain and analgesia: nucleus accumbens response to noxious stimuli changes in the presence of chronic pain. Neuron 66:149-160. CrossRef Medline

Berridge KC, Robinson TE (1998) What is the role of dopamine in reward: hedonic impact, reward learning, or incentive salience? Brain Res Brain Res Rev 28:309-369. Medline

Born JM, Lemmens SG, Rutters F, Nieuwenhuizen AG, Formisano E, Goebel R, Westerterp-Plantenga MS (2010) Acute stress and food-related reward activation in the brain during food choice during eating in the absence of hunger. Int J Obes (Lond) 34:172-181. CrossRef Medline

Breiter HC, Rosen BR (1999) Functional magnetic resonance imaging of brain reward circuitry in the human. Ann N Y Acad Sci 877:523-547. CrossRef Medline

Carson RE, Breier A, de Bartolomeis A, Saunders RC, Su TP, Schmall B, Der MG, Pickar D, Eckelman WC (1997) Quantification of amphetamine 
induced changes in [11C]raclopride binding with continuous infusion. J Cereb Blood Flow Metab 17:437-447. Medline

Cenci MA, Kalén P, Mandel RJ, Björklund A (1992) Regional differences in the regulation of dopamine and noradrenaline release in medial frontal cortex, nucleus accumbens and caudate-putamen: a microdialysis study in the rat. Brain Res 581:217-228. CrossRef Medline

Collura LA, Hoffman JB, Wilson ME (2009) Administration of human leptin differentially affects parameters of cortisol secretion in socially housed female rhesus monkeys. Endocrine 36:530-537. CrossRef Medline

Corp ES, Conze DB, Smith F, Campfield LA (1998) Regional localization of specific [125I]leptin binding sites in rat forebrain. Brain Res 789:40-47. CrossRef Medline

de Weijer BA, van de Giessen E, van Amelsvoort TA, Boot E, Braak B, Janssen IM, van de Laar A, Fliers E, Serlie MJ, Booij J (2011) Lower striatal dopamine $\mathrm{D} 2 / 3$ receptor availability in obese compared with non-obese subjects. EJNMMI Res 1:37. CrossRef Medline

Farooqi IS, Bullmore E, Keogh J, Gillard J, O'Rahilly S, Fletcher PC (2007) Leptin regulates striatal regions and human eating behavior. Science 317: 1355. CrossRef Medline

Figlewicz DP, Evans SB, Murphy J, Hoen M, Baskin DG (2003) Expression of receptors for insulin and leptin in the ventral tegmental area/substantia nigra (VTA/SN) of the rat. Brain Res 964:107-115. CrossRef Medline

Figlewicz DP, Bennett J, Evans SB, Kaiyala K, Sipols AJ, Benoit SC (2004) Intraventricular insulin and leptin reverse place preference conditioned with high-fat diet in rats. Behav Neurosci 118:479-487. CrossRef Medline

Figlewicz DP, Bennett JL, Naleid AM, Davis C, Grimm JW (2006) Intraventricular insulin and leptin decrease sucrose self-administration in rats. Physiol Behav 89:611-616. CrossRef Medline

First MB, Spitzer RL, Gibbon M, Williams JB (1995) Structured clinical interview for DSM-IV axis I disorders. New York: New York Psychiatric Institute.

Friston KJ, Frith CD, Liddle PF, Frackowiak RS (1991) Comparing functional (PET) images: the assessment of significant change. J Cereb Blood Flow Metab 11:690-699. CrossRef Medline

Friston K, Holmes A, Worsley K, Pline J, Frith C, Frackowiak R (1995) Statistical parametric maps in functional imaging: a general linear approach. Hum Brain Mapp 2:189-210.

Fletcher PC, Napolitano A, Skeggs A, Miller SR, Delafont B, Cambridge VC, de Wit S, Nathan PJ, Brooke A, O'Rahilly S, Farooqi IS, Bullmore ET (2010) Distinct modulatory effects of satiety and sibutramine on brain responses to food images in humans: a double dissociation across hypothalamus, amygdala, and ventral striatum. J Neurosci 30:14346-14355. CrossRef Medline

Fulton S, Pissios P, Manchon RP, Stiles L, Frank L, Pothos EN, Maratos-Flier E, Flier JS (2006) Leptin regulation of the mesoaccumbens dopamine pathway. Neuron 51:811-822. CrossRef Medline

Garthwaite TL, Martinson DR, Tseng LF, Hagen TC, Menahan LA (1980) A longitudinal hormonal profile of the genetically obese mouse. Endocrinology 107:671-676. CrossRef Medline

Gear RW, Aley KO, Levine JD (1999) Pain-induced analgesia mediated by mesolimbic reward circuits. J Neurosci 19:7175-7181. Medline

Hagan MM, Havel PJ, Seeley RJ, Woods SC, Ekhator NN, Baker DG, Hill KK, Wortman MD, Miller AH, Gingerich RL, Geracioti TD (1999) Cerebrospinal fluid and plasma leptin measurements: covariability with dopamine and cortisol in fasting humans. J Clin Endocrinol Metab 84:3579-3585. CrossRef Medline

Halaas JL, Gajiwala KS, Maffei M, Cohen SL, Chait BT, Rabinowitz D, Lallone RL, Burley SK, Friedman JM (1995) Weight-reducing effects of the plasma protein encoded by the obese gene. Science 269:543-546. CrossRef Medline

Haltia LT, Rinne JO, Merisaari H, Maguire RP, Savontaus E, Helin S, Någren K, Kaasinen V (2007) Effects of intravenous glucose on dopaminergic function in the human brain in vivo. Synapse 61:748-756. CrossRef Medline

Hodgkinson CA, Yuan Q, Xu K, Shen PH, Heinz E, Lobos EA, Binder EB, Cubells J, Ehlers CL, Gelernter J, Mann J, Riley B, Roy A, Tabakoff B, Todd RD, Zhou Z, Goldman D (2008) Addictions biology: haplotype-based analysis for 130 candidate genes on a single array. Alcohol Alcohol 43: 505-515. Medline

Horvitz JC (2000) Mesolimbic and nigrostriatal dopamine responses to sa- lient non-rewarding stimuli. Neuroscience 96:651-656. CrossRef Medline

Ishibashi K, Berman SM, Paz-Filho G, Lee B, Robertson C, Mandelkern MA, Wong ML, Licinio J, London ED (2012) Dopamine D(2)/D(3) receptor availability in genetically leptin-deficient patients after long-term leptin replacement. Mol Psychiatry 17:352-353. CrossRef Medline

Leinninger GM, Jo YH, Leshan RL, Louis GW, Yang H, Barrera JG, Wilson H, Opland DM, Faouzi MA, Gong Y, Jones JC, Rhodes CJ, Chua S Jr, Diano S, Horvath TL, Seeley RJ, Becker JB, Münzberg H, Myers MG Jr (2009) Leptin acts via leptin receptor-expressing lateral hypothalamic neurons to modulate the mesolimbic dopamine system and suppress feeding. Cell Metab 10:89-98. CrossRef Medline

Licinio J, Mantzoros C, Negrão A, Cizza G, Wong ML, Bongiorno PB, Chrousos GP, Karp B, Allen C, Flier JS, Gold PW (1997) Human leptin levels are pulsatile and inversely related to pituitary-adrenal function. Nat Med 3:575-579. CrossRef Medline

Liu J, Perez SM, Zhang W, Lodge DJ, Lu XY (2011) Selective deletion of the leptin receptor in dopamine neurons produces anxiogenic-like behavior and increases dopaminergic activity in amygdala. Mol Psychiatry 16: 1024-1038. CrossRef Medline

Malendowicz LK, Rucinski M, Belloni AS, Ziolkowska A, Nussdorfer GG (2007) Leptin and the regulation of the hypothalamic-pituitary-adrenal axis. Int Rev Cytol 263:63-102. CrossRef Medline

Meyer CR, Boes JL, Kim B, Bland PH, Zasadny KR, Kison PV, Koral K, Frey KA, Wahl RL (1997) Demonstration of accuracy and clinical versatility of mutual information for automatic multimodality image fusion using affine and thin-plate spline warped geometric deformations. Med Image Anal 1:195-206. CrossRef Medline

Minoshima S, Koeppe RA, Mintun MA, Berger KL, Taylor SF, Frey KA, Kuhl DE (1993) Automated detection of the intercommissural line for stereotactic localization of functional brain images. J Nucl Med 34:322-329. Medline

Nowak KW, Pierzchala-Koziec K, Tortorella C, Nussdorfer GG, Malendowicz LK (2002) Effects of prolonged leptin infusion on rat pituitaryadrenocortical function. Int J Mol Med 9:61-64. Medline

Ostlund RE Jr, Yang JW, Klein S, Gingerich R (1996) Relation between plasma leptin concentration and body fat, gender, diet, age, and metabolic covariates. J Clin Endocrinol Metab 81:3909-3913. CrossRef Medline

Petrovich GD, Holland PC, Gallagher M (2005) Amygdalar and prefrontal pathways to the lateral hypothalamus are activated by a learned cue that stimulates eating. J Neurosci 25:8295-8302. CrossRef Medline

Pezze MA, Heidbreder CA, Feldon J, Murphy CA (2001) Selective responding of nucleus accumbens core and shell dopamine to aversively conditioned contextual and discrete stimuli. Neuroscience 108:91-102. CrossRef Medline

Roitman MF, Stuber GD, Phillips PE, Wightman RM, Carelli RM (2004) Dopamine operates as a subsecond modulator of food seeking. J Neurosci 24:1265-1271. CrossRef Medline

Roseberry AG, Painter T, Mark GP, Williams JT (2007) Decreased vesicular somatodendritic dopamine stores in leptin-deficient mice. J Neurosci 27:7021-7027. CrossRef Medline

Rosenbaum M, Sy M, Pavlovich K, Leibel RL, Hirsch J (2008) Leptin reverses weight loss-induced changes in regional neural activity responses to visual food stimuli. J Clin Invest 118:2583-2591. Medline

Rothemund Y, Preuschhof C, Bohner G, Bauknecht HC, Klingebiel R, Flor H, Klapp BF (2007) Differential activation of the dorsal striatum by highcalorie visual food stimuli in obese individuals. Neuroimage 37:410-421. CrossRef Medline

Schmidt BL, Tambeli CH, Barletta J, Luo L, Green P, Levine JD, Gear RW (2002) Altered nucleus accumbens circuitry mediates pain-induced antinociception in morphine-tolerant rats. J Neurosci 22:6773-6780. Medline

Schwartz MW, Seeley RJ, Campfield LA, Burn P, Baskin DG (1996) Identification of targets of leptin action in rat hypothalamus. J Clin Invest 98:1101-1106. CrossRef Medline

Scott DJ, Heitzeg MM, Koeppe RA, Stohler CS, Zubieta JK (2006) Variations in the human pain stress experience mediated by ventral and dorsal basal ganglia dopamine activity. J Neurosci 26:10789-10795. CrossRef Medline

Scott DJ, Stohler CS, Koeppe RA, Zubieta JK (2007) Time-course of change in $[11 \mathrm{C}]$ carfentanil and $[11 \mathrm{C}]$ raclopride binding potential after a nonpharmacological challenge. Synapse 61:707-714. CrossRef Medline 
Seeman P, Wilson A, Gmeiner P, Kapur S (2006) Dopamine D2 and D3receptors in human putamen, caudate nucleus and globus pallidus. Synapse 60:205-211. CrossRef Medline

Siep N, Roefs A, Roebroeck A, Havermans R, Bonte ML, Jansen A (2009) Hunger is the best spice: an fMRI study of the effects of attention, hunger and calorie content on food reward processing in the amygdala and orbitofrontal cortex. Behav Brain Res 198:149-158. CrossRef Medline

Stice E, Spoor S, Bohon C, Veldhuizen MG, Small DM (2008) Relation of reward from food intake and anticipated food intake to obesity: a functional magnetic resonance imaging study. J Abnorm Psychol 117:924935. CrossRef Medline

Stice E, Yokum S, Blum K, Bohon C (2010) Weight gain is associated with reduced striatal response to palatable food. J Neurosci 30:13105-13109. CrossRef Medline

Stice E, Yokum S, Burger KS, Epstein LH, Small DM (2011) Youth at risk for obesity show greater activation of striatal and somatosensory regions to food. J Neurosci 31:4360-4366. CrossRef Medline

Stoeckel LE, Weller RE, Cook EW 3rd, Twieg DB, Knowlton RC, Cox JE (2008) Widespread reward-system activation in obese women in response to pictures of high-calorie foods. Neuroimage 41:636-647. CrossRef Medline

Stohler CS, Kowalski CJ (1999) Spatial and temporal summation of sensory and affective dimensions of deep somatic pain. Pain 79:165-173. CrossRef Medline

Stohler CS, Lund J (1995) Psychophysical and orofacial motor response to muscle pain: validation and utility of an experimental model. In: Brain and oral functions. Oral motor function and dysfunction (Morimoto T, Matsuya T, Takada K, eds), pp 227-237. Amsterdam: Elsevier Science.

Tobler PN, Fiorillo CD, Schultz W (2005) Adaptive coding of reward value by dopamine neurons. Science 307:1642-1645. CrossRef Medline

Volkow ND, Wang GJ, Telang F, Fowler JS, Thanos PK, Logan J, Alexoff D, Ding YS, Wong C, Ma Y, Pradhan K (2008) Low dopamine striatal D2 receptors are associated with prefrontal metabolism in obese subjects: possible contributing factors. Neuroimage 42:1537-1543. CrossRef Medline

Walker CD (2005) Nutritional aspects modulating brain development and the responses to stress in early neonatal life. Prog Neuropsychopharmacol Biol Psychiatry 29:1249-1263. CrossRef Medline
Wang GJ, Volkow ND, Logan J, Pappas NR, Wong CT, Zhu W, Netusil N, Fowler JS (2001) Brain dopamine and obesity. Lancet 357:354-357. CrossRef Medline

Watabe H, Endres CJ, Breier A, Schmall B, Eckelman WC, Carson RE (2000) Measurement of dopamine release with continuous infusion of [11C] raclopride: optimization and signal-to-noise considerations. J Nucl Med 41:522-530. Medline

Wilson ME, Fisher J, Brown J (2005) Chronic subcutaneous leptin infusion diminishes the responsiveness of the hypothalamic-pituitary-adrenal (HPA) axis in female rhesus monkeys. Physiol Behav 84:449-458. CrossRef Medline

Wood PB, Schweinhardt P, Jaeger E, Dagher A, Hakyemez H, Rabiner EA, Bushnell MC, Chizh BA (2007) Fibromyalgia patients show an abnormal dopamine response to pain. Eur J Neurosci 25:3576-3582. Medline

Worsley KJ, Evans AC, Marrett S, Neelin P (1992) A three-dimensional statisticalanalysis for CBF activation studies in human brain. J Cereb Blood Flow Metab 12:900-918. CrossRef Medline

Zhang X, Ashton-Miller JA, Stohler CS (1993) A closed-loop system for maintaining constant experimental muscle pain in man. IEEE Trans Biomed Eng 40:344-352. CrossRef Medline

Ziauddeen H, Farooqi IS, Fletcher PC (2012) Obesity and the brain: how convincing is the addiction model? Nat Rev Neurosci 13:279-286. Medline

Zink CF, Pagnoni G, Martin ME, Dhamala M, Berns GS (2003) Human striatal response to salient nonrewarding stimuli. J Neurosci 23:80928097. Medline

Zink CF, Pagnoni G, Martin-Skurski ME, Chappelow JC, Berns GS (2004) Human striatal responses to monetary reward depend on saliency. Neuron 42:509-517. CrossRef Medline

Zink CF, Pagnoni G, Chappelow J, Martin-Skurski M, Berns GS (2006) Human striatal activation reflects degree of stimulus saliency. Neuroimage 29:977-983. CrossRef Medline

Zubieta JK, Smith YR, Bueller JA, Xu Y, Kilbourn MR, Jewett DM, Meyer CR, Koeppe RA, Stohler CS (2001) Regional mu opioid receptor regulation of sensory andaffective dimensions of pain. Science 293:311-315. CrossRef Medline 